\title{
Human-social capital and market access factors influencing agro-processing participation by small-scale agripreneurs: The moderating effects of transaction costs
}

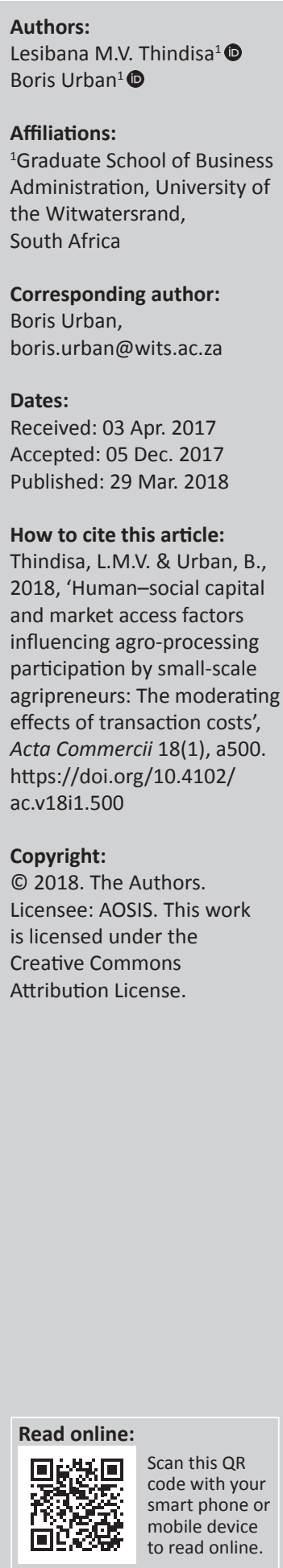

Orientation: Participating in the agriculture and agro-processing chain has the potential to enhance the competitive advantage of small-scale agricultural enterprises in South Africa.

Research purpose: The study empirically investigated the extent to which agro-processing participation is determined by human and social capital factors, while accounting for the moderating effects of transaction costs.

Motivation of the study: Research is required that examines levels of human and social capital of small-scale agripreneurs, as these act as major constraints towards improved competitiveness of agribusinesses.

Design: To test the study hypotheses, a structured questionnaire was administered to 166 small-scale agripreneurs at farmer gatherings across regions in South Africa.

Findings: Based on the survey results, both human and social capital factors showed a positive and significant influence on agro-processing participation. The findings further highlight the importance of market access and transaction costs to small-scale agripreneurs.

Practical implications: Policy-makers need to be aware of how human capital factors such as previous education and experience impact participation in agro-processing activities and help to mitigate transaction costs.

Contribution: Study findings are highly relevant to South Africa as agro-processing and value-adding activities are not always scale dependent, and hence, a focus on human and social capital is valuable.

\section{Introduction}

It is increasingly recognised that the exploitation of agro-processing entrepreneurial opportunities has the potential to enhance the competitive advantage of agribusinesses (World Bank 2016:14). Agro-processing typically refers to those activities that change agricultural, forestry and fisheries products into forms that facilitate easier handling and increase shelf life (Food and Agriculture Organisation [FAO] 1997:14). Several benefits of integrating the primary agriculture and agroprocessing industries have been noted in the literature which include among others, local economic growth and development via backward and forward linkages through providing opportunities for earning income in food production, processing, distribution, retailing and thus job creation encouraged by increased productivity from lower transaction cost (Dorosh \& Thurlow 2013:450; Fan, Brzeska \& Halsema 2013:141).

Despite the potential benefits that might accrue from participation in agro-processing and value addition activities, in South Africa (SA) small-scale agripreneurs are mainly confined to the informal sector and focused on primary agriculture, whereas participation in agro-processing and value addition activities requires agripreneurs to be flexible in production methods, and at the same time, they must pay attention to cost elements (Kaikkonen 2006:3; Jari \& Fraser 2009; Urban \& Xaba 2016:223). Several challenges face these small-scale agripreneurs, which include information asymmetry, lack of access to finance, lack of access to markets, inadequate and insufficient infrastructure, low human capital and low investments in technology (Louw et al. 2008:288; Uchezuba, Moshabele \& Digopo 2009:173). 
A critical review of the literature shows that obstacles to participation in agro-processing activities are exacerbated by the intensity of human capital requirements necessary for small-scale agripreneurs to navigate the different value chain phases in agro-processing by moving from upstream to downstream activities (World Bank 2016:26). Research reports that a lack of capacity, skills and knowledge at all levels of small and medium enterprises (SMES) is a major constrain towards improved competitiveness of agribusinesses (Nkosi et al. 2013; Uchezuba et al. 2009:173; Urban \& Xaba 2016:224). An inadequate set of entrepreneurial skills among rural agripreneurs limits agricultural development, specifically in terms of the management and operations of their enterprises (Oelofse \& Van der Walt 2015). Additionally, research finds that transaction costs significantly affect agricultural activities (Makhura 2001), and in general, high costs incurred by small and medium enterprises (SMEs) in the self-provision of infrastructure and distribution of finished goods are problematic (Mabuza, Ortmann \& Wale 2014:208; Obokoh \& Goldman 2016).

Recognising these problems facing small-scale agripreneurs, this study investigates the extent to which agro-processing participation (APP) is influenced by human-social capital and market access factors, while accounting for the moderating effect of transaction costs. The potential of agroprocessing to spur growth and development through backward and forward linkages with other sectors of the economy is widely acknowledged in the South African policy space (Department of Agriculture, Forestry and Fisheries [DAFF] 2012; National Development Plan [NDP] 2012). The Department of Land Reform and Rural Development has made it a priority to recapitalise as well as provide developmental support to land reform beneficiaries in rural communities to improve their capacity for sustainable economic agriculture (DAFF 2012). Similarly, the NDP (2010) in South Africa identifies the latent potential of agroprocessing industry to spur growth and development through backward and forward linkages with other sectors of the economy.

The first part of the study provides the theoretical and contextual foundations underlying the hypotheses formulated for empirical testing. The next part discusses the methodological design of the article and presents the results of the statistical analysis. The final part interprets the findings based on the empirical evidence and offers several recommendations.

\section{Literature review}

\section{Small-scale agricultural enterprises}

The agricultural sector includes all economic activities from the provision of farming inputs to actual farming and production (FAO 1997:16). Moreover, the agricultural sector remains crucial in addressing the triple challenges of poverty, unemployment and inequality (Shiimi, Taljaard \& Jordan 2012:43; World Bank 2013:21). In a globalised economy, agriculture is a crucial commercial activity, and agricultural enterprises are an integral part of economic activity for many countries in Africa, including South Africa. The contribution of the agricultural sector in developing effective entrepreneurial ecosystems in Africa is important (Muffato 2015).

South African agriculture is highly dualistic, characterised by a small number of commercial agricultural operations that are managed mainly by successful agripreneurs and a large number of small-scale agricultural enterprises consisting mainly of black struggling producers (DAFF 2012:5). Smallscale agripreneurs are confined to economic participation within the informal sector with a focus on primary agriculture, whereas commercial agripreneurs are located within the formal economy with footprints along the agriculture and agro-processing value chain (Fan et al. 2013:132).

To try and rectify this imbalance, the government has put in place policies, strategies and programmes aimed to migrate small-scale agricultural enterprises from the informal sector towards integration with the mainstream commercial agricultural economy (Randela, Alemu \& Groenewald 2008:453). Additionally, skills development of agriculturebased enterprises has been recognised as imperative (Meena, Prasad \& Singh 2009) particularly as competitive advantage stems from the possession and efficient utilisation of a unique set of assets such as natural resources, skills and knowledge and proximity to inputs and markets (Dorosh \& Thurlow 2013; Ortmann \& King 2010; Urban \& Kongo 2015).

\section{Transaction costs}

Transaction costs represent a critical factor in market participation by small-scale agricultural enterprises in South Africa (Makhura 2001; Ortmann \& King 2010:399). Transaction costs include sourcing trading partners, screening potential partners, sourcing and verifying information, negotiation, entering into exchange or agreement contracts, product transfer, monitoring and enforcing transaction (Randela et al. 2008:455). These types of costs are often regarded as barriers to efficient and effective participation by smallscale agricultural enterprises in various marketing channels resulting in a preference for a channel whose cost is minimal (Shiimi et al. 2012:46).

Transaction costs have a direct bearing on the integration of agriculture and agro-processing value chain, thus influencing the marketing channel selected by small-scale agripreneurs. These costs are likely to be high for small-scale agripreneurs because of poor logistics, poor infrastructure, information asymmetry, ineffective bureaucratic freight procedures and non-tariff barriers (Shiimi et al. 2012:47).

To combat and reduce the negative effects of transaction costs that small-scale agripreneurs typically encounter, the improvement of human and social capital has been recognised as essential (Louw et al. 2008; Shree \& Urban 2012). Breaking the cycle of unsustainability of small-scale agricultural enterprises requires complementary interventions that should focus on human capital to improve the skills and 
knowledge level of small-scale agripreneurs, while enhancing social capital and collective capacity of these producers (Randela et al. 2008:460).

\section{Human capital}

Considering the intensity of human capital requirements necessary for small-scale agripreneurs to progress from upstream to downstream agriculture and agro-processing value chain, skills and knowledge are pivotal in improving the competitiveness of agribusinesses (Louw et al. 2008; Uchezuba et al. 2009). Unger et al. (2011:343) conceptualise human capital as skills and knowledge that individuals acquire through investments in schooling, on-the-job training and other types of experience, where the ability to act entrepreneurial is related to such human capital variables as education, work experience, entrepreneurial experience, prior knowledge and experiential knowledge. Acquiring human capital is not only a result of formal education but also the accumulation of experience and knowledge over time. Human capital factors such as education and work experience influence the ability of entrepreneurs to recognise, identify and exploit business opportunities (Sheperd \& DeTienne 2005:93).

Levels of educational attainment are commonly considered to have implications for different types of entrepreneurial behaviour (Shree \& Urban 2012). Longitudinal research on the relationship between education and entrepreneurship shows that (1) better-educated entrepreneurs pursue more opportunity-based ventures; (2) less well-educated entrepreneurs are involved out of necessity; and (3) people who have a secondary-level education (high school) tend to work for salaries or wages (Xavier et al. 2013:45). Research also demonstrates that education increases individuals' self-confidence, general knowledge and self-efficacy, and ultimately their human capital which in turn increases their perceptions of feasibility and desirability of pursuing entrepreneurship (Krueger \& Brazeal 1994:92).

Following the literature in terms of the potential links between human capital and entrepreneurship, it is hypothesised that the human capital dimension of education is associated with APP, where this relationship is further influenced by transaction costs:

Hypothesis 1: Increased participation by small-scale agripreneurs in agro-processing activities is positively related to higher levels of human capital, where this relationship is moderated by transaction costs.

\section{Social capital}

The fundamental thrust of social capital theory is that networks and ties provide access to resources that can be leveraged to identify, discover and exploit entrepreneurial opportunities (De Carolis \& Saparito 2006:43). Social capital may be defined as all the potential resources located within and accessed through a derived network of relationships available to individuals or social units (Adler \& Kwon 2000:12).
Social capital consists of both bridging and bonding ties, where both weak and strong ties have potential to build social capital (Adler \& Kwon 2000:22). Small-scale agripreneurs may rely on industry organisations or study groups (weak ties) to access relevant information in terms of bridging social capital, while relying on family members (strong ties) to access funding in terms of bonding social capital (Shree \& Urban 2012). Individuals with higher levels of social capital are likely to be provided with enhanced access to information including trust from others. Entrepreneurs who possess high levels of social capital based on networks, personal ties and referrals are more likely to receive information, funding and other resources than entrepreneurs who are lower on social capital (Davidsson \& Honig 2003:303).

In situations where transaction costs are high, social capital has the potential to provide a significant contribution to the small-scale agripreneur's performance by providing access to information and reducing costs of coordination and contracting (Randela et al. 2008). Access to adequate, reliable and timely information gained through networking is likely to significantly reduce transaction costs (Jagwe \& Machethe 2011:110).

Recognising past empirical studies that highlight the importance of social capital in fostering entrepreneurship and the relevance of social capital in mitigating transactions costs, it is hypothesised that:

Hypothesis 2: Increased participation by small-scale agripreneurs in agro-processing activities is positively related to higher levels of social capital, where this relationship is moderated by transaction costs.

\section{Market access}

At regional, provincial and national level, market penetration and participation by small-scale agripreneurs are critical for sustainable agriculture and economic growth (World Bank 2013, 2016). Small-scale agripreneurs are faced with many difficulties in accessing long-term commercial market contracts (FAO 1997). Many small-scale agripreneurs are not able to participate in the marketplace for a wide variety of reasons, including poor infrastructure, lack of market transport, low volumes of products, market information asymmetry, inadequate experience on grades and standards, and insufficient and inadequate contractual agreements (Jagwe \& Machethe 2011:113).

Research indicates that when small-scale agripreneurs are faced with high transaction costs, they opt not to participate in formal market contracts and resort to spot markets which are not as rewarding (Asokan \& Singh 2003:567; Makhura 2001:21). Nonetheless, participation in formal contract markets is important as market specification contracts provide pre-harvest contractual agreements that engage the buyer to provide a market outlet to a farmer under preagreed conditions mostly entailing price, volume, quality and time of expected delivery. Both agripreneur and buyer benefit from price premium on quality and stability in the 
flow of supply of products specified at the market (FreiguinGresh, D'huese \& Anseeuw 2012:26). Moreover, resource providing contracts are akin to full vertical integration and require the buyer to provide a market outlet to the farmer where the buyer also delivers input packages on credit and corresponding technical assistance, thereby reducing transaction costs (Arlene et al. 2007:319).

Recognising that access to markets is pivotal to the sustainability and profitability of small-scale agripreneurs, while transaction costs influence access to markets, it is hypothesised that:

Hypothesis 3: Increased participation by small-scale farming agripreneurs in agro-processing activities is positively related to greater access to markets, where this relationship is moderated by transaction costs.

\section{Research design and methodology}

The agricultural sector in South Africa provided the setting of the study, where the focus was on the small-scale agripreneurs. The unit of enquiry was small-scale agricultural enterprises and unit of analysis was the small-scale agripreneur. A quantitative and cross-sectional research design was adopted which relied on a survey to collect data in order to investigate the proposed relationship between the variables under study. A structured questionnaire was administered to small-scale agripreneurs at farmer gatherings and/or meetings.

A number of ethical issues regarding consent and confidentiality were taken into consideration. A statement that guaranteed confidentiality was articulated in the cover letter to the questionnaire. Additionally, data collation instrument did not require respondents to indicate names. Lastly, data sets were coded and results reported in aggregates. The right to refusal by respondents declining participation was respected.

\section{Sampling and data collection}

The sample was extracted from the sample frame based on the farmer database obtained from the Provincial Department of Agriculture, which has an inclusive schedule of farmer gatherings and meetings. Classification of agribusiness size was determined according to AgriBEE charter (DAFF 2012). The AgriBEE charter is a sub-item of the government gazetted BBBEE Act 53 of 2003, stipulating small-scale agricultural enterprises employ between 1 and 50 people and have a maximum turnover of approximately $\mathrm{R} 10$ million per annum (Industrial Policy Action Plan [IPAP] 2013:45; Strategic Plan of the Department of Agriculture Forestry and Fisheries 2012). Sampling frames were obtained from the Provincial Departments of Agriculture. A convenience sampling technique was used to collect the data.

Once suitable dates and places were identified, trained field workers in the Gauteng, Limpopo and Western Cape provinces administered a survey physically. Based on the sampling selection criteria, an initial survey yielded a total of
578 qualifying respondents, of which 166 responses were received and served as the final sample ( $28.7 \%$ response rate). This was regarded as reasonable response rate, for an empirical survey-based study (Hair et al. 2010). Table 1 shows the listing of when and where data were collected.

\section{Instrument}

Based on previous research, suitable measures were identified particularly where there was empirical support for each construct as examined in the literature review section. Independent (IV), dependent (DV) and moderator (MV) variables were specified in line with each of the hypothesis. The study adopted referenced measures for the following constructs: human capital (IV), social capital (IV), market access (IV), transaction cost (MV) and agro-processing participation (DV).

To measure human capital (HC), six questions relating to levels of education and experience of the agripreneur ownermanager were solicited and included items such as years or level of education, years of industry specific experience, years of management experience and years of training sessions attended on industry specific task (Unger et al. 2011; Urban \& Kongo 2015).

Social capital (SC) was operationalised in terms of its relational aspects pertaining to membership of different organisations and family involvement (Adler \& Kwon 2000; Randela et al. 2008; Shree \& Urban 2012). Five questions were used to solicit data which included membership of industry organisation, cooperation with neighbouring commercial agripreneur, immediate family involved in agro-processing activities and cooperation with a mentor or strategic partner regarding value addition.

Access to markets (AM) was measured with six items relating to barriers to accessing markets (transport, volumes or prices), involvement in collective selling, selling channel preference and contract with agricultural advisor (Randela et al. 2008; Shiimi et al. 2012). Similarly, to determine levels of transaction costs (TC), four items relating to road infrastructure, electricity access to communications modes and access to market price information were solicited (Randela et al. 2008; Uchezuba et al. 2009; Watanabe, Jinji \& Kurihara 2009).

TABLE 1: Data collection.

\begin{tabular}{|c|c|c|}
\hline $\begin{array}{l}\text { Number of } \\
\text { completed surveys }\end{array}$ & Location and province & Farmer event \\
\hline 14 & Bronkhorstspruit - Gauteng & Training session on market access \\
\hline 15 & $\begin{array}{l}\text { Gauteng Department of } \\
\text { Agriculture Provincial Office }\end{array}$ & $\begin{array}{l}\text { Women in Agricultural and Rural } \\
\text { Development meeting }\end{array}$ \\
\hline 16 & De Deur - Gauteng & $\begin{array}{l}\text { Sedibeng Agricultural Cluster } \\
\text { meeting }\end{array}$ \\
\hline 64 & Tarlton - Gauteng & Baby Vegetable Farmers day \\
\hline 14 & Meyerton-Gauteng & Thiba-Tlala Agricultural Cluster \\
\hline 8 & Walkerville-Gauteng & Emfuleni Agricultural Cluster \\
\hline 20 & $\begin{array}{l}\text { Tzaneen Study Group - } \\
\text { Limpopo }\end{array}$ & $\begin{array}{l}\text { Study group on financial record } \\
\text { keeping }\end{array}$ \\
\hline 15 & $\begin{array}{l}\text { Oudtshoorn farmers, } \\
\text { Western Cape }\end{array}$ & Study group on marketing \\
\hline
\end{tabular}


The level of APP among respondents was measured with the following items: participation in utilising value addition and agro-processing machinery, participation in procuring value addition and agro-processing machinery and equipment and participation in accessing service providers in the area selling agro-processing machinery and equipment (Uchezuba et al. 2009; Watanabe et al. 2009).

Metric (i.e. interval and ratio scaled) data were measured on a 1 to 5 Likert scale, where ' 5 equals strongly agree and 1 equals strongly disagree'. In order to ensure that the instrument demonstrated sufficient face and content validity, a preliminary analysis via a pilot test to easily accessible respondents was undertaken $(n=15)$. This procedure ensured that the respondents had no difficulties in answering the questions and there was no problem in recording the data. As a precaution, common method response bias was methodologically controlled for by counterbalancing the question order, as well as safeguarding respondent anonymity which ensured that social desirability and item ambiguity were avoided to some extent (Podsakoff et al. 2003). Item statistics were calculated for each factor with satisfactory Cronbach's alpha (Hair et al. 2010) obtained for each of the factors: human capital (0.79), social capital (0.82), market access (0.77), transaction cost (0.74) and APP (0.83).

\section{Data analysis and model formulation}

Data collected were captured and coded on Excel software and analysed statistically using IBM Social Package for Social Scientist (SPSS) version 21 software. Descriptive statistics, Pearson product-moment correlations were calculated, and regression analyses results were used to test the hypotheses of the formulated models. Because the hypotheses were formulated to reflect the aggregate HC-participation, SC-participation and AM-participation relationships, the constructs were presented as consolidated scores at the first level of analysis. An equation (Model 1) was formulated that could explain agro-participation (DV) in terms of the three independent variables (IV) of human capital, social capital and market access, while considering the moderation effect (MV) of transaction costs on this relationship:

Model $1=\mathrm{PAA}=\left(\beta_{0}+\beta_{1} \mathrm{HC}+\beta_{2} \mathrm{SC}+\beta_{3} \mathrm{TC}+\beta_{4} \mathrm{AM}+\beta_{5} \mathrm{TC} \times\right.$ $\left.H C+\beta_{6} T C \times S C+\beta_{6} T C \times A M\right)+\varepsilon$

where: $P A A=$ participation by small-scale farming entrepreneur in agro-processing activities; $\beta_{0}=$ constant which is the value of $Y$ when $X$ is zero; $\beta i=$ correlation coefficient, Pearson's correlation coefficient for the purpose of this study; $H C=$ human capital; $S C=$ social capital; $T C=$ transaction cost; $A M=$ access to markets; $T C \times H C=$ moderation or interaction effect by human capital and transaction cost on $P A A ; T C \times S C=$ moderation or interaction effect by social capital and transaction cost on $P A A ; T C \times A M=$ moderation or interaction effect by access to markets and transaction cost on PAA.
$E=$ error term indicating proportion of $P A A$ that is not to be explained by constructs $H C, S C, T C, T C \times H C, T C \times S C$ and $T C \times A M$.

Hierarchical multiple regression analysis was used to analyse and test the degree and character of the DV, as a result of the IVs and the possible interaction effect of transaction costs. To test for moderation, the interaction effect between $\mathrm{HC} \times \mathrm{TC}$, $\mathrm{SC} \times \mathrm{TC}$ and $\mathrm{AM} \times \mathrm{TC}$ was examined to test whether the moderation effect is enhancing, buffering or antagonistic. Enhancing moderation is when transaction cost as moderator increases the effect of the predictor such as HC, SC or AM on the DV. Buffering moderation is when transaction cost as moderator decreases the effect of the predictor or independent variable, while antagonistic moderation is when the transaction cost as moderator reverses the effect of the predictor or independent variable on the DV (Aiken \& West 1991).

Consequently, to test for moderation, if $R^{2}$ from Model 3, which was stated as: Model $2=\mathrm{PAA}=\left(\beta_{0}+\beta_{1} \mathrm{HC}+\beta_{2} \mathrm{TC}+\right.$ $\left.\beta_{3} T C \times H C\right)+\varepsilon$, was greater than Model 2, which was stated as: Model $3=\mathrm{PAA}=\left(\beta_{0}+\beta_{1} \mathrm{HC}+\beta_{2} \mathrm{TC}\right)+\varepsilon$, but also greater than Model 1, which was stated as: Model $4=\mathrm{PAA}=\left(\beta_{0}+\right.$ $\left.\beta_{1} \mathrm{HC}\right)+\varepsilon$.

\section{Results \\ Sample characteristics}

Characteristics for the sample of respondents surveyed revealed that most respondents $(78 \%)$ were situated in the Gauteng Province, which is considered the hub of economic activity in South Africa and which has the highest number of both formal and informal entrepreneurs (Herrington \& Kelly 2012). The respondents reflect the typical small-scale farmer profile currently prevalent in South Africa where most are black people $(83 \%)$, are female $(63 \%)$ and are farming vegetables $(56 \%)$. This profile coincides with the Strategic Plan of Department of Agriculture, Forestry and Fisheries, in South Africa, which concedes that the majority of small-scale agripreneurs are African (black people) and that female agripreneurs are the backbone of many rural farming communities (World Bank 2013). Furthermore, approximately a third of respondents hold a Certificate or Diploma (32\%) as their highest qualification level. The respondents were engaged predominantly in secondary agro-processing activities, that is, sorting, slicing, grinding and labelling (42\%).

\section{Descriptive statistics and correlations}

Table 2 shows the descriptive and correlational statistics. The overall mean scores were relatively high, where the mean is the midpoint average on the 1-5 Likert scale. The highest mean score was for $\mathrm{HC}(M=3.97, \mathrm{SD}=0.86)$, followed by SC $(M=3.88, \mathrm{SD}=0.65)$. To understand the nature of the relationship between the variables, a correlation analysis was conducted.

Pearson product-moment correlations coefficients were calculated for each of the scales and are reported with levels 
of significance denoted in Table 2. The correlation matrix indicates that participation of small-scale agripreneurs was significantly and positively correlated with human capital $\left(r=0.38 ; R^{2}=0.14 ; p<0.01\right)$, social capital $\left(r=0.19 ; R^{2}=0.04 ;\right.$ $p<0.05)$ and market access $\left(r=0.18 ; R^{2}=0.03 ; p<0.05\right)$, but significantly and negatively correlated with transaction costs $(r=-0.43 ; p<0.01)$.

\section{Hypotheses testing}

Hypothesis 1 predicted that participation by small-scale agripreneur in agro-processing activities is positively related to human capital, where this relationship is moderated by transaction costs such that when transaction costs are high, there is a negative relationship, but when transaction costs are low, the relationship is positive. Table 3 shows the regression summary for each of the models formulated to reflect the various predictors.

For Model 1, an $R^{2}=0.14$ was obtained indicating that $14 \%$ variance in participation by small-scale agripreneurs was explained by human capital. This $R^{2}$ was significant with $F$ $(1164=26.90, p=0.00)$. Considering $R^{2}=0.14$, the effect size was classified as moderate. In terms of Model 2, an $R^{2}=0.24$ was obtained indicating that $24 \%$ variance in participation by small-scale agripreneurs was explained by human capital + transaction costs. This $R^{2}$ was significant with $F(2163=25.13$, $p=0.00)$, and the effect size was classified as moderate.

TABLE 2: Descriptives and correlation matrix.

\begin{tabular}{lccccccc}
\hline Variables & Mean & SD & APP & HC & SC & TC & AM \\
\hline $\begin{array}{l}\text { Agro-process } \\
\text { participation }\end{array}$ & 3.26 & 0.67 & 1.00 & $0.38^{* *}$ & $0.19 * *$ & $-0.43^{* *}$ & $0.18^{*}$ \\
Human capital & 3.97 & 0.86 & $0.38^{* *}$ & 1.00 & 0.14 & $-0.36^{* *}$ & 0.10 \\
Social capital & 3.88 & 0.65 & $0.19 * *$ & $0.14^{*}$ & 1.00 & $-0.30^{* *}$ & -0.05 \\
Transaction costs & 3.64 & 0.68 & $-0.43^{* *}$ & $-0.39 * *$ & $-0.30^{* *}$ & 1.00 & $-0.32^{* *}$ \\
Market access & 3.17 & 0.89 & $0.18^{*}$ & 0.10 & -0.05 & $-0.32 * *$ & 1.00 \\
\hline
\end{tabular}

SD, standard deviation; APP, agro-processing participation; HC, human capital; SC, social capital; TC, transaction costs; AM, access to markets.

*, Correlation is significant at the 0.05 level (1-tailed); **, Correlation is significant at the 0.01 level (1-tailed).

TABLE 3: Regression summary for agro-processing participation and human capital (Model 1) + TC (Model 2) + HC $\times$ TC (Model 3)

\begin{tabular}{lcccccccccc}
\hline Model & $\boldsymbol{R}$ & $\boldsymbol{R}^{2}$ & $\begin{array}{c}\text { Adjusted } \\
\boldsymbol{R}^{\mathbf{2}}\end{array}$ & & $\mathrm{SE}$ & \multicolumn{5}{c}{ Change statistics } \\
\cline { 5 - 10 } & & & & $\boldsymbol{R}^{2}$ change & $\boldsymbol{F}$ change & df 1 & df 2 & $\boldsymbol{p}$ \\
\hline 1 & 0.38 & 0.14 & 0.14 & 0.47 & 0.14 & 26.90 & 1 & 164 & 0.00 \\
2 & 0.49 & 0.24 & 0.23 & 0.44 & 0.24 & 24.13 & 2 & 163 & 0.00 \\
3 & 0.49 & 0.24 & 0.22 & 0.44 & 0.24 & 17.16 & 3 & 162 & 0.00 \\
\hline
\end{tabular}

Predictors: Human capital + transaction cost + HC $\times$ TC. Dependent variable: Participation in agro-processing activities by small-scale farming entrepreneur.

TABLE 4: Moderation effects between $\mathrm{HC}+\mathrm{TC}+\mathrm{HC} \times \mathrm{TC}$.

\begin{tabular}{|c|c|c|c|c|c|c|c|c|}
\hline \multirow[t]{2}{*}{ Variables } & \multicolumn{3}{|c|}{ Model 2 (HC+TC) } & \multicolumn{5}{|c|}{ Model $3(\mathrm{HC}+\mathrm{TC}+\mathrm{HC} \times \mathrm{TC})$} \\
\hline & B & SE & $\beta$ & B & SE & $\beta$ & $\Delta R^{2}$ & $\Delta F$ \\
\hline Intercept & $1.79 * *$ & 0.18 & - & $2.08 * *$ & 0.40 & - & - & - \\
\hline $\mathrm{HC}$ & $0.15 * *$ & 0.04 & 0.25 & -0.02 & 0.16 & -0.03 & - & - \\
\hline TC & $-0.34 * *$ & 0.08 & -0.33 & $-0.56 * *$ & 0.22 & -0.55 & - & - \\
\hline $\mathrm{HC} \times \mathrm{TC}$ & - & - & - & 0.09 & 0.09 & 0.29 & - & - \\
\hline $\mathrm{R}^{2}$ & $0.24 * *$ & - & - & $0.24 * *$ & - & - & 0.00 & - \\
\hline $\mathrm{F}$ & $25.13 * *$ & - & - & $17.16 * *$ & - & - & - & 9.97 \\
\hline
\end{tabular}

In terms of Model 3 , an $R^{2}=0.24$ was obtained indicating that $24 \%$ variance in participation by small-scale agripreneurs was explained by human capital + transaction cost $+\mathrm{HC} \times \mathrm{TC}$. This $R^{2}$ was significant with $F(3162=17.16, p=0.00)$, and the effect size was classified as moderate.

The assessment of the moderation effect via hierarchical regression in $\mathrm{H} 1$ is shown in Table $4 . R^{2}$ for Models 2 and 3 was constant at 0.24 to 0.24 indicating a null differential, albeit statistically significant at the $p<0.01$ level. Based on the statistically significant results, H1 is supported, albeit limited variance is explained by $\mathrm{HC}$ and TC interactions.

Hypothesis 2 predicted that participation by small-scale agripreneurs in agro-processing activities is positively related to social capital, where this relationship is moderated by transaction costs such that when transaction costs are high, there is a negative relationship, but when transaction costs are low, the relationship is positive. Table 5 shows the regression summary for each of the models formulated to reflect the various predictors.

For Model 1, an $R^{2}=0.04$ was obtained indicating that $4 \%$ variance in participation by small-scale agripreneurs was explained by social capital. This $R^{2}$ was significant with $F$ $(1164=6.23, p=0.01)$. Considering $R^{2}=0.04$, the effect size was classified as low. In terms of Model 2 , an $R^{2}=0.19$ was obtained indicating that $19 \%$ variance in participation by small-scale agripreneurs was explained by social capital + transaction costs. This $R^{2}$ was significant with $F(2163=18.87$, $p=0.00$ ), and the effect size was classified as moderate. In terms of Model 3, an $R^{2}=0.19$ was obtained indicating that $19 \%$ variance in participation by small-scale agripreneurs was explained by social capital + transaction cost + SC*TC. This $R^{2}$ was significant with $F(3162=12.90, p=0.00)$, and the effect size was classified as moderate.

The assessment of the moderation effect via hierarchical regression in $\mathrm{H} 1$ is shown in Table $6 . R^{2}$ for Models 2 and 3

TABLE 5: Regression summary for APP and SC (Model 1) + TC (Model 2) + SC $\times$ TC (Model 3).

\begin{tabular}{lccccccccc}
\hline Model & $\boldsymbol{R}$ & $\boldsymbol{R}^{2}$ & $\begin{array}{c}\text { Adjusted } \\
\boldsymbol{R}^{2}\end{array}$ & SE & \multicolumn{5}{c}{ Change statistics } \\
\cline { 5 - 10 } & & & & $\boldsymbol{R}^{2}$ change & $\boldsymbol{F}$ change & df 1 & df 2 & $\boldsymbol{p}$ \\
\hline 1 & 0.19 & 0.04 & 0.03 & 0.50 & 0.04 & 6.23 & 1 & 164 & 0.01 \\
2 & 0.43 & 0.19 & 0.18 & 0.45 & 0.19 & 18.87 & 2 & 163 & 0.00 \\
3 & 0.44 & 0.19 & 0.18 & 0.45 & 0.19 & 12.90 & 3 & 162 & 0.00 \\
\hline
\end{tabular}

Predictors: Social capital + transaction cost + SC $\times$ TC. Dependent variable: participation in agro-processing activities by small-scale farming entrepreneurs.

APP, agro-processing participation; SC, social capital; SE, standard error; TC, transaction costs.

TABLE 6: Moderation effects between $\mathrm{SC}+\mathrm{TC}+\mathrm{SC} \times \mathrm{TC}$.

\begin{tabular}{|c|c|c|c|c|c|c|c|c|}
\hline \multirow[t]{2}{*}{ Variables } & \multicolumn{3}{|c|}{ Model 2 (SC + TC) } & \multicolumn{5}{|c|}{ Model $3(\mathrm{SC}+\mathrm{TC}+\mathrm{SC} \times \mathrm{TC})$} \\
\hline & B & SE & $\beta$ & B & SE & $\beta$ & $\Delta R^{2}$ & $\boldsymbol{F}$ \\
\hline Intercept & $2.02 * *$ & 0.18 & - & $2.35 * *$ & 0.39 & - & - & - \\
\hline SC & 0.07 & 0.08 & 0.07 & -0.16 & 0.24 & -0.15 & - & - \\
\hline TC & $-0.41 * *$ & 0.07 & -0.41 & $-0.62 * *$ & 0.23 & -0.62 & - & - \\
\hline $\mathrm{SC} \times \mathrm{TC}$ & - & - & - & 0.15 & 0.15 & 0.26 & - & - \\
\hline$R^{2}$ & $0.19 * *$ & - & - & $0.19 * *$ & - & - & 0.00 & - \\
\hline$F$ & $18.80 * *$ & - & - & $12.90 * *$ & - & - & - & 5.91 \\
\hline
\end{tabular}


was constant at 0.19 to 0.19 indicating a null differential, albeit statistically significant at the $p<0.01$ level. Based on the statistically significant results, $\mathrm{H} 2$ is supported, albeit limited variance is explained by SC and TC interactions.

Hypothesis 3 predicted that participation by small-scale agripreneurs in agro-processing activities is positively related to market access, where this relationship is moderated by transaction costs such that when transaction costs are high, there is a negative relationship, but when transaction costs are low, the relationship is positive. Table 7 shows the regression summary for each of models formulated to reflect the various predictors.

For Model 1, an $R^{2}=0.02$ was obtained indicating that $2 \%$ variance in participation by small-scale agripreneurs was explained by market access. This $R^{2}$ was non-significant with $F(1164=3.15, p=0.04)$. Considering $R^{2}=0.02$, the effect size was classified as low. In terms of Model 2 , an $R^{2}=0.18$ was obtained indicating that $18 \%$ variance in participation by small-scale agripreneurs was explained by market access + transaction costs. This $R^{2}$ was significant with $F(2163=18.35$, $p=0.00)$, and the effect size was classified as moderate. In terms of Model 3, an $R^{2}=0.19$ was obtained indicating that $19 \%$ variance in participation by small-scale agripreneurs was explained by market access + transaction cost $+\mathrm{AM} \times \mathrm{TC}$. This $R^{2}$ was significant with $F(3162=12.36, p=0.00)$, and the effect size was classified as moderate.

The assessment of the moderation effect via hierarchical regression in $\mathrm{H} 3$ is shown in Table 8. $R^{2}$ for Models 2 and 3 was constant at 0.18 to 0.19 indicating a slight differential and statistically significant at the $p<0.01$ level. Based on the statistically significant results, H3 is partially supported, albeit limited variance is explained by MA and TC interactions.

To examine the joint effects of all three of the IVs, a regression model summary was conducted. The results are displayed in Table 9, where a significant $R^{2}=0.26(p<0.00)$ was obtained meaning that $26 \%$ variance in participation by small-scale agripreneurs was explained by the IV variables jointly. Considering that the $R^{2}$ was significant with $F(7158=7.97$, $p=0.00)$, the effect size was classified as moderate.

\section{Discussion}

The research purpose of this study was to empirically test the extent to which APP by small-scale agripreneurs is influenced by human and social capital factors and access to markets, while accounting for the moderating effects of transaction costs. The findings from this study show that the relationship between human capital and participation in agro-processing activities, when moderated by transaction costs, had a positive and significant influence on small-scale agripreneurs. This finding concurs with assertions by World Bank (2013) that higher human capital is necessary for participation in downstream agro-processing activities. Study findings indicate that a third (32\%) of respondents hold a Certificate or Diploma as their highest qualification level, whereas a quarter $(42 \%)$ was engaged in secondary agro-processing activities. Study findings when read in conjunction with past studies are apparent that higher levels of human capital have been associated with the ability of individuals to recognise and exploit entrepreneurial opportunities more efficiently (Sheperd \& DeTienne 2005).

Human capital represents investment in education and skills, and thus, entrepreneurs provide tangible and intangible resources to the firm. These intangible resources are property of the individuals that have been accumulated via education and experience (Shree \& Urban 2012). Knowledge, skills and experience are fundamental antecedents of human capital and increase the cognitive ability of individuals, resulting in the likelihood of more productive entrepreneurial activity (Urban \& Kongo 2015).

Similarly, findings from this study indicate that relationship between social capital and participation in agro-processing activities, when moderated by transaction costs, had a positive and significant influence on small-scale agripreneurs. Agripreneurs that worked collaboratively and maintained networks had advantage over competitors who did not (Johnson, Suarez \& Lundy 2013). This study indicates that the greater proportion of small-scale agriprenuers belonged to industry or farmer association. Agro-processing firms compete in complex supply chains that are information intensive and require coordination along stages of value chain. In instances where markets fail and transaction costs are high, social capital has the potential to provide information

TABLE 7: Regression summary for APP and AM (Model 1) + TC (Model 2) moderation effect + AM $\times$ TC (Model 3).

\begin{tabular}{lllllcccccc}
\hline Model & $\boldsymbol{R}$ & $\boldsymbol{R}^{2}$ & Adjusted $\boldsymbol{R}^{2}$ & $\mathrm{SE}$ & \multicolumn{5}{c}{ Change statistics } \\
\cline { 5 - 10 } & & & & & $\boldsymbol{R}^{2}$ change & $\boldsymbol{F}$ change & df 1 & df 2 & $\boldsymbol{p}$ \\
\hline 1 & 0.14 & 0.02 & 0.01 & 0.50 & 0.2 & 3.15 & 1 & 164 & 0.04 \\
2 & 0.43 & 0.18 & 0.17 & 0.45 & 0.18 & 18.35 & 2 & 163 & 0.00 \\
3 & 0.43 & 0.19 & 0.17 & 0.46 & 0.19 & 12.36 & 3 & 162 & 0.00 \\
\hline
\end{tabular}

Predictors: Market access + transaction cost + AM $\times$ TC. Dependent variable: Participation in agro-processing activities by small-scale farming entrepreneurs.

AM, Access to markets; APP, agro-processing participation; TC, transaction costs;

TABLE 8: Moderation effects between AM + TC + AM $\times$ TC.

\begin{tabular}{|c|c|c|c|c|c|c|c|c|}
\hline \multirow[t]{2}{*}{ Variables } & \multicolumn{3}{|c|}{ Model 2 (AM+TC) } & \multicolumn{5}{|c|}{ Model $3(\mathrm{AM}+\mathrm{TC}+\mathrm{AM} \times \mathrm{TC})$} \\
\hline & B & SE & $\beta$ & B & SE & $\beta$ & $\Delta R^{2}$ & $\boldsymbol{F}$ \\
\hline Intercept & $2.15 * *$ & 0.22 & - & $1.80 * *$ & 0.55 & - & - & - \\
\hline AM & -0.001 & 0.14 & 0.00 & 0.34 & 0.50 & 0.18 & - & - \\
\hline TC & $-0.43 * *$ & 0.08 & -0.43 & -0.11 & 0.46 & -0.11 & - & - \\
\hline AM*TC & & - & - & 0.31 & 0.45 & -0.32 & - & - \\
\hline$R^{2}$ & $0.18 * *$ & - & - & $0.19 * *$ & - & - & 0.01 & - \\
\hline$F$ & $18.35^{* *}$ & - & - & $12.36 * *$ & - & - & - & 0.59 \\
\hline
\end{tabular}

AM, access to markets; TC, transaction costs. $(N=166)$.

$* *, p<0.01$.

TABLE 9: Regression model summary for joint effect of independent variables.

\begin{tabular}{lccccccccc} 
Model & $\boldsymbol{R}$ & $\boldsymbol{R}^{2}$ & Adjusted $\boldsymbol{R}^{2}$ & $\mathrm{SE}$ & \multicolumn{5}{c}{ Change statistics } \\
\cline { 5 - 10 } & & & & & $\boldsymbol{R}^{2}$ change & $\boldsymbol{F}$ change & df 1 & df 2 & $\boldsymbol{p}$ \\
\hline 1 & 0.51 & 0.26 & 0.23 & 0.44 & 0.26 & 7.97 & 7 & 158 & 0.00
\end{tabular}

Predictors: (Constant), interaction effect $\mathrm{AM} \times \mathrm{TC}$, interaction effect $\mathrm{HC} \times \mathrm{TC}$, interaction Predictors: (Constant), interaction effect $\mathrm{AM} \times \mathrm{TC}$, interaction effect $\mathrm{HC} \times \mathrm{TC}$, interaction
effect SC $\times$ TC, social capital, human capital, market access, transaction cost. Dependent variable: Participation in agro-processing activities. 
and thus reduce the cost of contracting and coordination (Johnson et al. 2013).

Intangible assets emanating from social capital such as relational resources are critical for relationships to be established within a social network (Shree \& Urban 2012). Intangible assets such as reputation and networks can significantly influence the speed and degree of market access (Adler \& Kwon 2000). An entrepreneur's social network may greatly influence their ability to identify and acquire external resources and their ability to use these resources for additional product development, production and promotion. Previous research attests that it is beneficial for entrepreneurs to connect themselves with people involved in their supply chains, distribution and other businesses, as it eases the accessibility to specific resources (Shree \& Urban 2012).

However, the relationship between market access and participation in agro-processing activities, when moderated by transaction costs, was negative, albeit significant. Recognising that most agricultural areas are located in rural areas characterised by poor infrastructure and information asymmetry (World Bank 2013), small-scale agripreneurs face high transaction costs forcing them to choose marketing channels with minimal costs, such as the 'spot market', which are informal and intermittent by nature, thus a preferred mode of distribution for small-scale agricultural enterprises. By accounting for transaction costs and market access, the findings highlight the importance that these variables have on APP by small-scale agripreneurs.

\section{Recommendations and implications}

There are several important practitioner, policy and research implications emanating from the findings of this study.

- Policy-makers should consider prioritising entrepreneurship training as a vehicle to improve sustainability and profitability of small-scale agricultural and agroprocessing enterprises through enterprise and supplier development programmes, additionally via inclusion of entrepreneurship as a training prerequisite in the agricultural training institutions.

- Practitioners need to be aware of how previous education and experience impacts participation in agro-processing activities. These variables often lead to the development of experientially acquired skills or expertise which will lead in turn to more knowledgeable actions and decisions (Unger et al. 2011). Industry specific incubation facilities should be accessible to agripreneurs to attain agroprocessing experientially acquired skills. Additionally, sector-specific information hubs would mitigate access and ease of information dissemination. Lastly, industry organisation should consider providing after care support earmarked for agro-processing start-up agribusinesses.

- In line with AgriBEE, agro-processing companies and corporates should consider increasing enterprise development (ED) spend for the benefit of SME processors and small-scale agripreneurs. ED spend should be allocated towards market access, access to finance or incubation to improve the human capital and social capital of SME agro-processors.

- Small-scale agripreneurs must strive to form alliances and connect themselves with individuals involved in wider supply chains, distribution and other businesses, as it eases their accessibility to specific resources and the marketplace. It is recommended that small-scale agripreneurs should consider entering into business partnerships and mentorships programmes with neighbouring commercial agripreneurs and agroprocessors to enhance their social capital quotient.

- Increasing the social capital base of small-scale agripreneurs would improve relational-based conditions needed for effective mentoring and coaching of smallscale agribusinesses and could further help achieve harmonious and effective mentoring relationships (Matabooe, Venter \& Rootman 2016).

- Policies, strategies and programmes need to be developed to support a greater use of networking by small-scale agripreneurs, which will allow them to compete and share their experience on a broader platform. Excursion missions would empower small-scale agripreneurs to appreciate the agriculture and agro-processing dynamics.

- Development financial institutions including government funding should consider value chain financing, which will encourage linkages and integration of agriculture and agro-processing value chain..

- Policy-makers are encouraged to enhance levels of human capital among small-scale agripreneurs, because levels of education positively influence participation in agroprocessing activities. Moreover, human capital increases the capability of small-scale agripreneurs to mitigate transaction costs and increase their participation in agroprocessing activities, through increased market access. Agriculture and agro-processing training colleges should include entrepreneurship and agro-processing pedagogy to assist agripreneurs to consider agricultural activities as agribusiness ventures.

\section{Limitations and future research}

This study is not without limitations. For instance, there was an absence of analysis of firm survivor bias in the study sample. This is, in principle, an important methodological issue because firm survival itself may be determined by human capital (Unger et al. 2011). Consequently, the results of the study cannot be generalised to all business ventures. The study is also limited by its reliance on broad-based indicators of human and social capital. Future studies could be more fine grained and investigate how the human capital dimensions are complemented by social capital, particularly as social capital is one of the most significant sources of knowledge for entrepreneurs. Future studies may also benefit by focusing on variables not included in the study, especially as institutional support (Jagwe \& Machethe 2011) and the implementation of massive government rural capital infrastructure projects have been highlighted as ways to change the negative influences of transaction costs faced by agripreneurs. 


\section{Conclusion}

The study has relevance in a broader African context, because in a globalised economy, agricultural enterprises are an integral part of economic activity for many emerging economies, such as South Africa (Urban \& Xaba 2016). Accordingly, a third of the respondents (32\%) indicated that they hold a Diploma as the highest qualification. Predominantly, respondents (42\%) participated in secondary agro-processing activities. Accordingly, the study findings demonstrate that human and social capital factors positively influence agripreneurs to navigate the rigours of upstream to downstream agro-processing activities (World Bank 2016:26).

Against this backdrop, researching human capital and social capital as drivers of participation in agro-processing activities is valuable. Enhancing education and knowledge and developing networks at all levels of agro-processing value chain while simultaneously reducing transaction costs can significantly influence small-scale agripreneurs in terms APP.

\section{Acknowledgements Competing interests}

The authors declare that they have no financial or personal relationships that may have inappropriately influenced them in writing this article.

\section{Authors' contributions}

L.M.V.T. identified the sample and conducted the empirical work of the study. B.U. wrote the article and helped conceptualise the study.

\section{References}

Adler, P.S. \& Kwon, S.W., 2000, 'Social capital: The good and the bad and the ugly', in L.L. Eric (ed.), Knowledge and social capital, pp. 126-154, ButterworthHeinemann, Boston, MA.

Aiken, L.S. \& West, G.S., 1991, Multiple regression: Testing and interpreting interactions, Sage, London.

Arlene, A.D., Manyong, V.M., Omanya, G., Mignouna, H.D., Bokanga, M. \& Odhiambo G., 2007, 'Small-scale market participation under transactions costs: Maize supply and fertilizer demand in Kenya', Food Policy 33(20), 318-328.

Asokan, S.R. \& Singh, G., 2003, 'Role and constraints of contract farming in agroprocessing industry', Indian Journal of Agricultural Economics 58(3), 566-568.

Department of Agriculture, Forestry and Fisheries (DAFF), 2012, Strategic plan for department of agriculture, forestry and fisheries 2012/13-2016/17, viewed 18 September 2015, from http://www.nda.agric.za/doaDev/topMenu/StratPlan 201213-201617.pdf

Davidsson, P. \& Honig, B., 2003, 'The role of social and human capital among nascent entrepreneurs', Journal of Business Venturing 18(3), 301-331. https://doi.org/ 10.1016/S0883-9026(02)00097-6

De Carolis, D.M. \& Saparito, P., 2006, 'Social cognition and entrepreneurial opportunities: A theoretical framework', Entrepreneurship Theory and Practice 30, 41-56. https://doi.org/10.1111/j.1540-6520.2006.00109.x

Dorosh, P. \& Thurlow, J., 2013, 'Agriculture and small towns in Africa', Agricultural Economics 44(4-5), 449-459. https://doi.org/10.1111/agec.12027

Fan, S., Brzeska, J. \& Halsema, A., 2013, From subsistence to profit: Transforming small-scale farms, International Food Policy Research Institute, Washington, DC.

Food and Agriculture Organisation (FAO), 1997, The state of food and agriculture small towns in Africa, viewed 19 September 2015, from http://www.fao.org

Freiguin-Gresh, S., D'huese, M. \& Anseeuw, W., 2012, 'Demystifying contract farming: Evidence from rural South Africa', Agrekon: Agricultural Economics Research, Policy and Practice in Southern Africa 51(3), 24-51. https://doi.org/10.1080/0303 1853.2012.749567

Hair, J.F., Black, W., Babin, B.J. \& Anderson, R.E., 2010, Multivariate data analysis: A global perspective, 7th edn., Pearson, Upper Saddle River, NJ.
Herrington, M. \& Kelly, D., 2012, African entrepreneurship. Sub-Saharan African regional report, International Development Research Centre, Ottawa, Canada.

Industrial Policy Action Plan (IPAP), 2013, Implementation framework for New Growth Path (NGP), viewed 21 April 2015, from http://www.thedti.gov.za

Jagwe, J.N. \& Machethe, C., 2011, 'Effects of transaction costs on choice of selling point: A case of small-scale banana growers in the Great Lakes region of Central Africa', Agrekon: Agricultural Economics Research, Policy and Practice in Southern Africa 50(3), 109-123. https://doi.org/10.1080/03031853.2011.617866

Jari, B. \& Fraser, G.C.G., 2009, 'An analysis of institutional and technical factors influencing agricultural marketing among small-scale farmers in the Kat River Valley, Eastern Cape Province', South Africa. African Journal of Agricultura Research 4(11), 1129-1137.

Johnson, N.J., Suarez, R. \& Lundy, M., 2003, 'The importance of social capital in Columbian rural agro-enterprises', Paper presented at the 25th International Columbian rural agro-enterprises', Paper presented at the 25th International
Conference of Agricultural Economists (IAAE), Durban, South Africa, 16-22nd August.

Kaikkonen, V., 2006, 'Exploring the dilemmas of small business growth - The case of rural food-processing micro firms', Journal of Enterprising Culture 14(87), 1-14. https://doi.org/10.1142/S0218495806000076

Krueger, N.F. \& Brazeal, D.V., 1994, 'Entrepreneurial potential and Potential entrepreneurs', Entrepreneurship Theory and Practice 18(3), 91-105.

Louw, A., Jordaan, D., Ndanga, L. \& Kirsten, J.F., 2008, 'Alternative marketing options for small-scale-farmers in the wake of changing agri-food supply chains in South Africa', Agrekon: Agricultural Economics Research, Policy and Practice in Southern Africa 47(3), 287-308. https://doi.org/10.1080/03031853.2008.9523801

Mabuza, L.M., Ortmann, G. \& Wale, E., 2014, 'Effects of transaction costs on mushroom producers' choice of marketing channels: Implications for agricultural market access in Swaziland', South Africa Journal of Economic and Management Sciences 17(2), 207-219. https://doi.org/10.4102/sajems.v17i2.494

Makhura, M.T., 2001, 'Overcoming transaction cost barriers to market participation of small-scale farmers in Limpopo Province', Unpublished PhD thesis, University of Pretoria, Pretoria.

Matabooe, M.J., Venter, E. \& Rootman, C., 2016, 'Understanding relational conditions necessary for effective mentoring of black-owned small businesses: A South African perspective', Acta Commercii 16(1), 1-11. https://doi.org/10.4102/ac. African pri.327

Meena, M.S., Prasad, M. \& Singh, R, 2009, 'Constraints perceived by rural agroprocessors in adopting modern post-harvest technologies', Indian Research Journal of Extension Education 9(1),1-5.

Muffato, M.S.M., 2015, 'The present state of entrepreneurship ecosystems in selected countries in Africa', African Journal of Economic and Management Studies 6(1),

National Development Plan (NDP), 2010, Macro-economic plan of South Africa adopted by cabinet for implantation, viewed 26 March 2015, from http://www. thedti.gov.za

National Development Plan (NDP), 2012, Macro-economic plan of South Africa adopted by cabinet for implementation, viewed 29 June 2015, from http://www. thedti.gov.za

Nkosi, E., Bounds, M., Thomas, A. \& Goldman, G., 2013, 'Skills required for the management of Black-owned small enterprises in Soweto', Acta Commercii 13(1), 1-10. https://doi.org/10.4102/ac.v13i1.18

Obokoh, L.O. \& Goldman, G., 2016, 'Infrastructure deficiency and the performance of small- and medium-sized enterprises in Nigeria's Liberalised Economy', Acta Commercii 16(1), 1-10. https://doi.org/10.4102/ac.v16i1.339

Oelofse, R. \& Van Der Walt, J.L., 2015, 'An evaluation of South African worker cooperatives against specified business success factors', Journal of Contemporary Management 12(2), 289-312.

Ortmann, G.F. \& King, R.P., 2010, 'Research on agri-food supply chains in Southern Africa involving small-scale farmers: Current status and future possibilities', Agrekon: Agricultural Economics Research, Policy and Practice in Southern Africa 49(4), 397-417. https://doi.org/10.1080/03031853.2010.526428

Podsakoff, P.M., Mackenzie, S.B., Jeong-Yeon, L. \& Podsakoff, N.P., 2003, ‘Common method biases in behavioral research: A critical review of the literature and recommended remedies', Journal of Applied Psychology 88(5), 879-903. https:// doi.org/10.1037/0021-9010.88.5.879

Randela, R., Alemu, Z.G. \& Groenewald, J.A., 2008, 'Factors enhancing market participation by small-scale cotton farmers', Agrekon: Agricultural Economics
Research, Policy and Practice in Southern Africa 47(4), 451-469. https://doi.org/ Research, Policy and Practice in So
$10.1080 / 03031853.2008 .9523810$

Sheperd, D.A. \& Detienne, D.R., 2005, 'Prior knowledge, potential financial reward and opportunity identification', Entrepreneurship: Theory and Practice 29(1), a1-112. https://doi.org/10.1111/j.1540-6520.2005.00071.x

Shiimi, T., Taljaard, P.R. \& Jordaan, H., 2012, 'Transactions costs and cattle farmers' choice of marketing channel in North-Central Namibia', Agrekon: Agricultural Economics Research,Policy and Practice in Southern Africa 51(1), 42-58. https:// doi.org/10.1080/03031853.2012.649543

Shree, S. \& Urban, B., 2012, 'Internationalisation processes and links with capital factors: The case of South Africa', Teorija Ir Praktika (Business Theory and Practice) 13(4), 292-303. https://doi.org/10.3846/btp.2012.31

Strategic Plan of Department of Agriculture Forestry and Fisheries, 2012, viewed 18 September 2015, from http://pmg.org.za/committee-meeting/14311

Uchezuba, I.D., Moshabele, E. \& Digopo, D., 2009, 'Logistical estimation of the probability of mainstream market participation among small-scale livestock
farmers: A case study of the Northern Cape Province', Agrekon: Agricultural farmers: A case study of the Northern Cape Province, Agrekon: Agricultural
Economics Research, Policy and Practice in Southern Africa 48(2), 171-183. Economics Research, Policy and Practice in Southe
https://doi.org/10.1080/03031853.2009.9523822 
Unger, J.M., Rauch, A., Frese, M. \& Rosenbusch, N., 2011, 'Human capital and entrepreneurial success: A meta-analytic review', Journal of Business Venturing 26(3), 341-358. https://doi.org/10.1016/j.jbusvent.2009.09.004

Urban, B. \& Kongo, M., 2015, 'The relevance of human capital on firms performance: A focus on the retail industry in Kinshasa. DRC', Acta Commercii 15(1), 1-9. https://doi.org/10.4102/ac.v15i1.261

Urban, B. \& Xaba, G., 2016, 'Enterprise skills and performance: An empirical study of small-scale farmers in Kwa-Zulu Natal', Journal of Contemporary Management 13(2), 222-245.
Watanabe, M., Jinji, N. \& Kurihara, M., 2009, 'Is the development of the agroprocessing industry pro-poor? The case of Thailand', Journal of Asian Economics 20(3), 443-455. https://doi.org/10.1016/j.asieco.2009.04.004

World Bank, 2013, Growing Africa: Unlocking the potential of agribusiness, viewed 21 April 2015, from http://siteresources.worldbank.org

World Bank, 2016, Agriculture in Africa: Telling facts from myths, viewed 04 November 2015, from http://beta.worldbank.org/en/programs/africa-myths-and-facts

Xavier, R., Kelley, D., Kew, J., Herrington, M., Vorderwulbecke, A. \& GERA, 2013, Global entrepreneurship monitor 2012 report, Babson College, Babson, MA. 